\title{
Ritual Capital for Rural Livelihood and Sustainable Tourism Development in Indonesia
}

\author{
Yerik Afrianto Singgalen", Gatot Sasongko, Pamerdi Giri Wiloso
}

Development Studies of Interdisciplinary Faculty, Satya Wacana Christian University, Jl. Diponegoro No.52-60, Salatiga, Indonesia 50711

Received Juni 25, 2019/Accepted August 6, 2019

\begin{abstract}
Sustainable livelihood approach has been a strategic approach that can improve the economy of rural communities and create harmonization of socio-cultural, economic, environmental and political development through policies. However, it is holistic and contextual, enabling the existence of different capital characteristics formed based on the community's culture. The Indonesian context shows that customary rituals of the community in Kakara and Limau villages in North Halmahera Regency are forms of capital that mobilize claims and access to capital such as natural, human, physical, financial, and social capital. This article aims to describe the ritual capital in rural livelihood for sustainable tourism development. Key informants involved were leaders of community, traditions, religion and rural government and they were interviewed to obtain in-depth information about the ritual capital. The results indicate that the ritual capital was integrated with the rural tourism development, enhancing the capabilities of the customary community in the Kakara and Limau Village to access other capital. This finding supports the argument explaining that ritual capital is a livelihood asset in the context of tourism development in North Halmahera Regency, Indonesia.
\end{abstract}

Keywords: ritual capital, sustainable livelihood approach, rural livelihood, sustainable tourism development

*Correspondence author,email: singgalen.yerik@gmail.com

\section{Introduction}

Research on livelihoods in rural areas has developed since the 1990s and become an important issue in discussing efforts to alleviate rural poverty (McAreavey \& McDonagh, 2011). In its development, livelihood studies began to be elaborated with the perspective of environmental sustainability (Costa, 2001), politics (Baumman, 2000), and even human rights for sustainable development (Moser et al., 2001). The Sustainable Livelihood Framework is seen as an effective strategy to solve poverty problems (Norton \& Foster, 2001). Chambers and Conway (1991) classified resources as livelihood assets that can be used to alleviate poverty. Furthermore, Scoones (1998) described livelihood assets as natural, economic, human, and social capital to maintain livelihood sustainability in rural areas through agricultural intensification or extensification, livelihood diversification, and migration. Meanwhile, Ashley and Carney (1999) developed a sustainable livelihood framework based on empirical experience as a practical guide for practitioners and development agents. The results of the identification of various aspects that influence livelihood diversification are developed into a sustainable livelihood framework and used as a basis for policy formulation (Rakodi, 2002). Nevertheless, the framework for achieving the sustainability of rural communities' livelihoods still needs to be seen contextually, especially in developing countries such as Indonesia which has a diverse cultural archipelago.

Indonesian cultural diversities are a reflection of the determinants of livelihood diversification. Cultural differences have a significant influence on people's access to capital. This indicates that the conceptual framework of sustainable livelihood in developing countries, in this case Indonesia, cannot be generalized and has the potential to show the use of different forms of capital in accordance with their respective cultures. Several previous researchers still adopted the conventional framework as a measure of the livelihood context's observations of gender, socio-economic, environmental, political and institutional issues, but did not implicitly describe the main forms of capital used to access other capital (Adzawala \& Kane, 2018; Albore, 2018; Belete, 2018; Gebru et al., 2018; Gelan, 2018 ).

The sustainable livelihood Aapproach (SLA) is a framework used by researchers in describing the context of rural livelihoods. However, social capital is still considered as the main capital of cultured societies (Sedana et al., 2011). Several previous researchers identified religious and spiritual aspects as a form of capital supporting the livelihood system of local communities (Sergej, 2012). On the other hand, Wepener (2010) asserted that for the cultured 
communities, ritual became the capital to access social capital. Swart et al., (2010) found that the convergence of ritual and social capital was a strategic step to alleviate poverty. Rituals played a role as manifestations of customary community' traditions to social capital. Wang and Woods (2013) also showed the existence of ritual capital as a space for community interaction mobilizing social movements to develop villages. For the cultured communities, the ritual capital was the essence of reconstructed social norms as a basis for networking (Barbulescu, 2014). Meyer (2013) placed ritual capital in the formation of social capital to clarify each domain and its effect on the development of access to other capital.

In tourism, the most frequently observed studies by previous researchers are not on the ritual but cultural capital. Cultural capital contributes to the development of a region (Richards \& Rotaru, 2013). In the context of tourism development in Indonesia, cultural capital is the main capital of the community to access social and financial capital (Ketut, 2012). The cultural capital experiences diversification into social and financial capital so as to accelerate regional development (Macbeth et al., 2004). However, the researchers believe that cultures, in the Indonesian context, need to be viewed partially, and cannot be generalized in the context of cultural capital, or to classify them as a part of social capital. As a country with diverse culture, rituals are the characteristic of cultural attractions as well as characteristics that distinguish the patterns of social interaction. Therefore, studies of ritual capital need to be improved by focusing on the case of customary community in Indonesia.

Specifically, this article offers an idea to place the rituals of customary community in North Halmahera-Indonesia as capital to access social, natural, human, financial and physical capital acoording to Chambers and Conway (1991) on sustainable livelihood framework. Studies of sustainable livelihood in Indonesia are still limited to the definition of traditional or cultural values as social capital by emphasizing norms, beliefs and networks in accessing other capital (Turner, 2007; Neilson \& Shonk, 2014;). Therefore, it is necessary to thoroughly elaborate on the role of ritual capital in the livelihoods of rural communities to achieve sustainable tourism development in North Halmahera Regency, Indonesia.

\section{Methods}

Considering the framework of the SLA adopted and reconstructed by Chambers and Conway (1991) on livelihood assets, this study offers an idea to consider ritual as a form of capital supporting sustainable livelihoods. Meanwhile, these considerations are based on the traditional rituals of the Limau and Kakara community in North Halmahera Regency, Indonesia. A reflection on the philosophy of local culture embodied in rituals and norms or universal values are collectively constructed as guidelines for community social life. This shows that before becoming social capital, ritual acts as an intermediary as well as authentic cultural saga. To strengthen the argument, there is a need of an initiative examining how ritual becomes the main capital for accessing social and other capital so as to support sustainable livelihoods and become a strategic step towards achieving sustainable development.

This study was done in a qualitative manner to describe the ritual capital that mobilized the access to the Limau and Kakara villages in accessing the social, natural, human, financial, physical, and natural capital. Meanwhile, the data was collected through in-depth interview, observation and document studies. A focus group discussion (FGD) was done and involved customary traditional stakeholders, community leaders, and local governments to obtain valid and credible information. The data was reconstructed by using triangulation techniques to ensure that there were similarities in the results of in-depth interviews, observations, and document studies (Kippendorf, 1980). The researchers also used FGD with the Limau community to explore information (Krueger, 1994) from key informants in such a short time (Hines, 2000). Barrows (2000) stated that FGD is an approach that allows researchers to obtain in-depth information. The information obtained was reported in detail based on the purpose of this research, which is to describe the role of ritual capital in a sustainable rural tourism development. Meanwhile, the proposed framework of livelihood assets can be seen in Figure 1 .

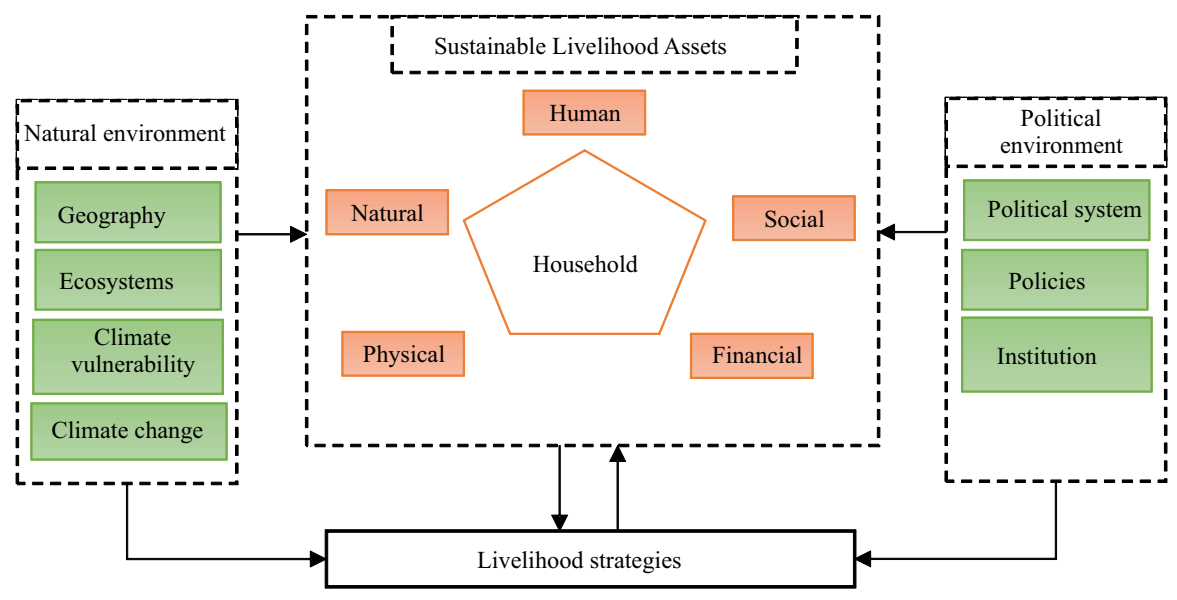

Figure 1 The proposed framework (Based on Chambers \& Conway (1991)). 
The appreciation of culture started from the recognition of the existence of local wisdom in rituals and traditions that supported the sustainability of people's livelihoods (James \& Bansilal, 2010). The trajectory of people's livelihoods experienced transformations due to the influence of acculturation and assimilation which caused social to economic inequality and environmental damage, so it needed to be prevented by integrating the value of local culture in the development (Cottyn, 2018). Each region had a different cultural context, thus the access to capital also had a significant difference. The sustainable livelihood framework described by Chambers and Conway (1991) provided an opportunity to identify capital in accordance with the context of each region. Therefore, this article describes ritual capital as an asset that plays an important role in the sustainability of tourism development in the region. Furthermore, a livelihood system of traditional community is described in accordance with the tradition of Limau and Kakara people in North Halmahera Regency, Indonesia.

\section{Results and Discussion}

This paper presents the livelihood system of the traditional community in North Halmahera Regency, Indonesia which refers to ritual capital and five livelihood capitals such as human, social, natural, financial, and physical capital.

Ritual capital It was the cultural essence of the Limau and Kakara villages community because of the sacred values that reflected the authenticity of the characteristics of the livelihoods of the local customary community.

In the context of the Limau community, fishing was known as Ngahu, while farming was Isitlah O Totoro. The ritual inherent in the livelihoods of the Limau community was the Seri Kodoba ritual (a respect for eagles) which formed collective values in the Makiriwo, Balelan and Babari, or Balilila traditions which meant for guarding and helping each other in farming and fishing activities. The Seri Kodoba ritual process was divided into several stages such as replacing the hawk bird replica house (Seri Kodoba Yodagali), surrounding the hawk bird replica house (Seri Kodoba Yogiloli), eating together as a form of brotherhood (Seri Kodoba Maino), giving handicrafts from the sons and grandchildren of the ancestors (Seri Kodoba Simomoku), rhyming between sons and daughters-in-law of the ancestors (Seri Kodoba Makabata), and eating together (Seri Kodoba Mangale). The Seri Kodoba ritual was such a social glue as well as a guideline for people's lives in a social harmony integrated with the Limau community livelihoods.

In the context of the Kakara community, fishing was known as Oriadodoto Yoyaungyaung, while farming was known as Obira Biranga Yototo Dumule. The rituals inherent in the Kakara community livelihoods could be seen based on the characteristics of fishermen and farmers. As a fisherman, fishing ritual was known as $O^{\prime}$ Dodoto with a number of taboos (Pamali-pamali) to avoid the nature punishment (O'Tulaka). Therefore, the tradition was started since the boat making process (Homa O Ngitiri) to pushing the boat to the sea (Oturun Ngotiri). Meanwhile, the relationship between the boat owners and fishermen in fishing activities was known as Tongohi Ahi Homa, which was a patron-client relationship where the boat owners could enjoy the fishes, but they must be responsible for the needs of individuals who sailed. The philosophy adopted by the fishermen was $O$ Gahioko Yo Kaibo De Yo Yawungu which referred to go fishing together to catch fishes.

On the other hand, as a farmer, the tradition was started from the land cultivating process (Imadumule) to the planting process (Hirono O Raki Igono) with a social gathering system known as O'Do Tomo. The philosophy adopted by the farmers was $O$ 'Naga Imatomakokirio which meant that everyone would call and remind each other. This indicated that the collective actions inherent in the Kakara community livelihoods were identical to the rituals and traditions. Meanwhile, various collective actions in the traditional rituals of the Kakara community were also manifested in cleaning the village (Haberin O Kampong), visiting sick people (Matulung), helping others to build houses (Otau Homakokirio Yohigopo), cleaning the tomb (Siboso O Kubur), helping others who were mourning in preparing for the funeral ( $O$ Yohonenge), helping others who were rejoicing in preparing for the party (Kokirio), and harvesting sea worms together (Falo Pariama). Thus, these rituals became a form of capital to access other capital.

The rituals become capital when it was used to achieve other goals, such as accessing social, natural, human, and physical capital. Kotalaha et al. (2018) showed that a tradition where people used the local wisdom of Makiriwo aimed to access social and economic capital. In the context of the Limau Village community, the Seri Kodoba ritual was the basis of the relationship between humans and the creator through good cooperation between fellow humans, besides that humans must also preserve the environment as a source of livelihood. Similar to the context of the Kakara Village community, the philosophy of Hibualamo was such a guideline in maintaining social ethics in the community, forming an economic system of mutual cooperation-based communities and implementing traditional environmental conservation methods. This means that the people of Limau and Kakara villages had traditional ways to maintain a balance between social, economic and environmental development. In the Indonesian context, these rituals in a tradition formed a concept of social wisdom that contributed to social, economic, and environmental development (Robaa \& Tolossa, 2016; Dereje \& Abeje, 2018; Njatrijani, 2018; Pranoto \& Wibowo, 2018).

Social capital Social capital had been discussed in a social science since 1981 (Harper, 2001). Social capital is defined as a part of social organizations, such as trust, norms and networks, which can improve community efficiency by facilitating coordinated action (Putnam, 1993), and the idea was come from his previous study in United States (Putnam, 2000). Furthermore, his work on "Bowling Alone", Putnam's (2000) contributions exceeded his professional boundaries by reaching a wider public in a political context. In addition, social capital is defined by Pierre Bourdieu as a resource, actual or virtual, which converges on an individual or group because it has a long-lasting network in the form of introductory reciprocity and recognition that is more or less institutionalized (Bourdieu \& Wacquant, 1992). Besides, Bourdieu and Wacquant (1992) and Putnam (1993), James 
Coleman defines social capital based on its function, as a variation of different entities that have similar characteristics (Coleman, 1994). Nevertheless, these definitions were contextual in different cultures. This shows that social capital was holistic because of the complexity of social structures built on different rituals and traditions.

In the context of North Halmahera, social capital was established from the ritual capital. This shows the customary community's capability of the Kakara and Limau villages that constructed the norms in social interaction. The Seri Kodoba ritual for the Limau community strengthened the social relations of the community in the concept of brotherhood of blood-related relationships, so that trust and networking were based on norms through the practice of helping each other in difficult and happy conditions manifested in the Balelan, Babari and Balilila traditions.

The Hibualamo philosophy for the Kakara community strengthened the social relations of the community in the concept of brotherhood of regional transitional relations while upholding multi-cultural tolerance and inter-religious relations so as to establish trust and norm-based networks manifested in the cultural attractions of Kokirio, Imakihirono, Otau Yogihopo, Matulung, Siboso O kubur, and O Nyawa Yohonenge. The fundamental difference between the concept of cultural and ritual capital proposed in this study was in the context of tradition. This refers to the rituals of the Kakara and Limau communities that developed into social capital. In contrast to the context of European culture, Bourdieu (1986) emphasized the use of social capital by elite groups, especially those who had financial capital but were limited to cultural capital (Robbins, 2000). In addition, in the context of American culture, Coleman (1998) found that social capital was an asset that could be developed into human capital. Furthermore, Putnam (2000) as a politician, viewed the social capital as a resource at the social level. The three explained different backgrounds to the process of forming social capital, but this article emphasizes that rituals in the culture of the Kakara and Limau communities encouraged the formation of social capital.

Social interaction as a capital was a reconceptualization of social functions which emphasized various changes in the economic, political, environmental dimensions, and even institutions due to the pattern of social interaction of the community (Robison et al., 2002). Therefore, the studies on social capital were well developed and related to the dimensions of economic development and the political conditions of an area (Rothstein, 2001; Fukuyama, 2002; Rankin, 2002). However, social capital was contextual and could not be generalized (Hall, 1999). This shows that social capital had different formations according to the norms developed by the customary community. Dhesi (2000) illustrated that social capital had a significant influence on the community development to access other capital. This article shows that the social capital of the Kakara and Limau community was such a strategy to maintain the local cultural community as well as strengthen the capability of access to other capital. Whiteley (2000) described the use of social capital to accelerate economic growth so as to improve people's welfare. In addition, social capital was also a consideration in formulating appropriate policies for the development of the household economy in accordance with the culture of local communities (Woolcock, 1998).

Natural capital The availability and ease of access and utilization of natural resources as capital could not be separated from ritual capital, as well as the capabilities of the Kakara and Limau community in accessing natural resources, utilizing and maintaining environmental ecology through sacred rituals. The community livelihoods in Kakara and Limau villages were inseparable from being farmers and subsistent fishermen. In the context of the Kakara community, the settlements in the archipelago area made the work as fishermen (Oriadodoto Yoyaungyaung) becoming more dominant, compared to the work as farmers (Obira Biranga Yototo Dumule). The communal livelihoods enabled the patron-client relations and collective actions to be part of the dynamics of the livelihoods of rural communities in the islands. It was different with the case of the Limau community context which was located on the coastal area where there were balanced numbers of fishermen ( $\mathrm{ggahu})$ and farmers ( $O$ Totoro) due to the access to land and water resources and fisheries around their settlements.

In the context of Kakara and Limau villages, the access capability to the land and water resources and fisheries were mobilized as well as controlled by local culture through traditions and rituals, so that environmental conditions were maintained (Moe et al., 2015). In fact, Ekins et al,. (2003) stated that to manage natural resources in accordance with the principles of sustainable development, human capital and qualified financial capital were highly needed. This article describes the cultural context of the Kakara and Limau community by showing the availability, ease of access to natural resources and utilization relevant to the principle of sustainable development.

The rituals became such a function of environmental sustainability control. In the context of the Seri Kodoba ritual by the Limau community, they were reminded of the rituals describing a story of greedy ancestral utilizing excessive resources so as to cause mutual loss. It was a form of remorse. Thus, the Seri Kodoba ritual saga was passed down from generation to generation as a reminder to keep the sustainability of the surrounding environment as a source of livelihood. As for the traditional context Hibualamo for the Kakara community, it was a reminder to be always thankful for the O Gikiri Moi Jou Madutu (the Ultimate Concern) creation by preserving the environment through the Haberin $o$ Kampong and Falo Pariama ritual to avoid a disaster known as $O$ Katula. This shows that the Kakara and Limau communities had understood the consequences of overexploiting natural resources, thus they reconstructed the traditional sustainable development methods through rituals in the traditions of local communities.

For rural communities, the availability and ease of access to natural resources were the indicators of sustainable livelihoods (Nawrotzki et al., 2012). Furthermore, Gariggos et al. (2018) stated that optimizing the sustainability of natural resources was highly dependent on the availability of human and social capital. Cronje and Moolman (2013) showed that financial capital was needed to access human capital. This article shows that capital rituals in the Kakara and Limau community's culture provided easy access to natural capital without having to access financial capital first. 
This was regulated in the Hibualamo cultural groups in the $O$ Higaro customary government structure known as Adati Majojo. The ownership recognition of the region was respected by all tribes who lived in Northern Halmahera. Meanwhile, each tribe had their own rituals and traditions in terms of natural resource management to meet the needs of the local community. The property ownership was inherited to the next generation through oral traditions witnessed by traditional stakeholders and respected by all communities in residential areas, allowing the current generation to obtain inheritance in the form of agricultural land from the ancestors. Thus, it could be seen that the availability, ease of access, and utilization of natural resources could not be separated from various rituals in the local cultural tradition.

Financial capital Financial capital included debt and equity, known as capital structure (Van Praag, 2003). The idea of financial capital was developed in empirical studies of Small and Medium-sized Enterprises (Wiklund \& Sepherd, 2005). Furthermore, Bollingtoft et al. (2003) showed that the efforts to achieve the sustainability of Small and Medium-sized Enterprises required the access to different capital such as human, physical, financial and other capital. In addition, Gracial and Martinez (2007) argued that limited access to capital was such a challenge to the sustainability of the Small and Medium-sized Enterprises. This showed that the capital access played an important role in achieving the economic sustainability.

In the context of North Halmahera, financial capital could be accessed from the accumulation of ritual, social and natural capital. This also showed the capability of the Kakara and Limau communities to access financial capital. The paradigm of financial capital developed globally was not entirely relevant to the traditional economic system, but was slowly replacing it. The exchanging goods system used to be a form of traditional economic transactions of the Kakara and Limau communities. However, it had changed as there were multi-ethnic relations between customary community in North Halmahera and other communities with different economic systems. For example, the economic system introduced by the Ternate (Handoko, 2017), Arabian, Chinese, Portuguese, Spanish, Dutch, and Japanese (Amal, 2010) kingdoms and other tribal communities such as Bugis, Buton, and Makassar (Lapian, 2009). In the context of Limau society, farming and fishing were traditional economic activities to meet daily needs. The crops and fishes could be exchanged for goods owned by their neighbours or other residents according to family and individual needs. In fact, to achieve crop effectiveness, the Limau community had a tradition of working on land to collectively harvest the crops known as Makiriwo. Since a trading system with currency values implemented, the Limau community began to make their fishes and crops as trading commodities.

In the context of Kakara community, farmers were called Obira Biranga Yototo Humule and fishermen were called Ori Adodoto Yoyaungyaung. Farming activities were done collectively with various rituals asking for mutual cooperation in working on land (Imadomule tradition) to working on the coconuts (Hirono O'Raki Igono tradition). In addition, the fishing activities were also done collectively and followed with various rituals, including rituals for mutual cooperation in boat building (Homa O Ngitiri tradition), boat launching (Oturun Ngotiri tradition), and fishing activities ( $O$ dodoto, Yo Yawungu, and Pamali-pamali). In the traditional economic system of the Kakara community, there was a relationship between the boat owner (Tongoni ahi homa) and the worker (Ori O'dodoto). The boat owner was responsible for every worker's needs, and treated them as partners, not subordinates. Thus, social trust and harmony were formed in traditional economic activities. In fishing activities, there were several taboos ( $O$ Katula), where people were not allowed to speak dirty, lie, slander other people or fight with fellow fishermen, complain during fishing, dispose of any impurities in the sea, and there should be no quarrels with fellow family members before going to the sea. This showed that the Kakara community in traditional economic activities continued to uphold socio-cultural values and pay attention to the environmental sustainability. The rituals formed trust in the accumulation of financial capital. Fukuyama (1995) emphasized that trust played an important role in the social system to access financial capital.

The combination of ritual, social, and natural capital allowed the Kakara and Limau community to access financial capital. The global financial capital paradigm based on the exchange of natural resource assets in currency values was highly vulnerable to crises due to dependence on supply and demand systems (Luchian, 2015). In the context of the Kakara and Limau community, globalization with a modern trading system did not completely replace the traditional economic system. The access to financial capital could be achieved by utilizing accumulated ritual, social, and natural capital. Thus, clothing, shelter and food needs could be met without having to sacrifice the socio-cultural aspects nor exploit natural resources. As a form of adaptation in response to the global economic development, the Kakara and Limau community utilized ritual, social, natural, and financial capital to access human capital.

Human capital Human capital was defined as competence, knowledge and personal attributes united with the skills to produce economic value (Sullivan \& Sheffrin, 2003). Knowledge and skills were forms of capital, and the capital was an intentional investment obtained through education and training (Schultz, 1961). Becker (1994) emphasized that human capital could not be transferred like land or labor. Therefore, human capability to survive was determined by the access to human capital. In the context of North Halmahera, human capital could be accessed through the accumulation of ritual, social, natural, and financial capital. Education helped increasing the capacity of human resources and became a major need. Structurally, the education level was one indicator in the development of human resources. Human capital could strengthen access to ritual, social, natural, and financial capital.

In the context of Kakara and Limau community, the access to human capital could be achieved by accumulating ritual, social, natural, and financial capital. Nevertheless, the capability to optimize human capital was still weak. This could be seen from the minimal quantity of human resources with a higher education background in the Kakara and Limau 
village. Naping et al. (2013) showed that the history of the society in North Halmahera in relation to education began in 1909 by the zendings in Tobelo who attended an elementary level carpentry school (ambachtschool) which succeeded in attracting local community participation. The education began to develop in the 1930s after the colonial government carried out a population census, allowing a public school with a three-year study period and using local languages as the daily language (volksschool). In the New Order era, education played an important role in regional and national economic development as well as being a strategic step to solve literacy problems.

In the colonial period, formal education was part of a foreign culture. The Kakara and Limau community's culture developed through speaking rather than writing, while the education system applied emphasized in reading and writing. This showed the existence of cultural shock between the local communities with unilateral cultural induction, so that not many participated in the education system. Along with its development, education became a prestige among the people and was developed into a symbol of honor in the social level that had its own value besides being the customary or community leaders. The higher the education, the more respected the person. This indicated that a symbolic value of the newly formed social status was formed because not everyone was considered capable of completing the education. As it developed, the higher the education quality, the higher the costs that must be met.

For the Kakara and Limau community, formal education was important for the next generation so that the accumulated ritual, social, natural, and financial capital were used to pay the fee. This was done to make the graduates became agents of change that contributed to the future village development. The Limau community was definitely aware of the importance of human capital for the next generation. The accumulation of human capital was a form of adaptation to the global economic demand as well as a coping strategy to maintain their culture (Kuzmin \& Shakhno, 2018). In rural tourism development, human resource capacity had a very important role to play in improving the economy while anticipating acculturation and assimilation (Kotarski, 2012). However, human capital had an important role in the economic activity (Natallia, 2014). Therefore, efforts to access human capital could be done by attending schools (Maman et al., 2018).

Physicalcapital Physical capital was a concept reconstructed on a corporeal sociology, referring to an approach to human relations and identity which was basically a socially realized subject (Shilling, 2004). In addition, Galor and Moav (2004) found that the accumulation of physical capital contributed to the economic growth in development, however the transformation of physical capital into human capital was very likely to occur if there was a shift in the value of a form of capital to other capital. In the context of North Halmahera, physical capital accessed by the Kakara and Limau community were manifested in the form of infrastructure to support people's livelihoods as farmers and fishermen. Physical capital, in this case, referred to the access to infrastructure which could be achieved by utilizing ritual, social, natural, financial and human capital.

In the context of the Kakara and Limau community, infrastructure development for personal and public interests could be done collectively through mutual cooperation in accordance with their respective traditions, although in its development, the construction of public facilities and prefacilities had become the responsibility of the rural government. The availability and access to physical capital were still dominated by the policies of the regency and subregency governments, especially the policies of the rural government. The development of Kakara and Limau village focused on optimizing the rural tourism potential by making their culture as a touristy attraction. Therefore, various physical infrastructures supporting tourism activities were established collectively as an embodied form of support in spontaneous participation. The Kakara and Limau community participated in the process of planning, implementing, and evaluating rural tourism development programs so that the consequences could be well anticipated. The government played a role in providing supporting facilities, but the community determined its sustainability (Dwivedi \& Hussain, 2018).

The access to physical capital could be obtained through cultural and structural approaches. The Kakara and Limau community tried to achieve the convergence of the two approaches by combining the activities of the VillageOwned Enterprises (BUMDes) in the tourism sector in supporting infrastructure development programs which were then carried out in cooperation in accordance with the traditions of each village. Tanjung (2019) showed that facilities and infrastructure for supporting tourism in the villages established on collective action were a part of social capital that was able to realize economic growth evenly as anticipatory measures of social inequality issues. This showed that there was a use of ritual, social, natural, financial, and human capital in the development of supporting infrastructure for rural tourism. Capital accumulation increased the capability of the community to access physical capital while strengthening previous capital. Thus, the capability to access physical capital could be achieved through cultural and structural approaches.

The role of ritual capital in rural livelihood and sustainable tourism development The description of the ritual capital of the Kakara and Limau community illustrated the capability to achieve sustainable rural tourism development through traditional approaches. The ritual capital was the main capital that mobilized access to other forms of capital for sustainable livelihood. This finding shows the existence of renewal in the form of capital, especially ritual capital, which was more explicit than the cultural capital based on the perspective of Bourdieu (1986) when he expressed the cultural capital concept of European society. Basically, the European culture context was different from the one in Indonesia. In Indonesia, Sumadi (2012) found that cultural capital became the basis of tourism sustainability that was able to encourage economic growth in the community. This indicated that tourism affected the livelihoods of people around the touristy destinations, while mobilizing access to certain forms of capital. Nonetheless, Romanos and Jenkins (2013) revealed that there was a 
vulnerability to cultural changes due to tourism development. Thus, it could be seen that the availability of resources and access to cultural capital did not guarantee the authenticity of local culture. In fact, Picard (2008) also found that a change in cultural identity was a result of tourism development.

In the context of the Kakara and Limau community in North Halmahera, the availability of resources and access to ritual, social and natural capital had been utilized since the pre-colonial period, long before tourism was adopted as a development approach. The transformation of the form of ritual capital into social and natural capital had become a strategy to maintain the sustainability of local people's livelihoods while strengthening local culture. The financial capital was only known after the existence of multi-ethnic relations with a "currency" based trading system. Furthermore, the human capital was known to the public after the education system was implemented by the zendings in the colonial era and the physical capital was known from the post-colonial period to the enactment of the government system of the Republic of Indonesia (NKRI). This showed that the sustainability of traditional community livelihoods could be achieved by utilizing the ritual, social and natural capital. Meanwhile, the access to financial, human, and physical capital was a form of adaptation as well as coping strategies in response to various changes caused by multiethnic interactions in the context of globalization and political conditions in the development.

The community-based rural tourism development approaches were relevant to the context of Kakara and Limau community because of the access capability to the ritual, social, and natural capital (Taylor, 2017). The ritual capital as a motor of development was one of the strategies to achieve equity in improving people's economy (Richard \& Rotariu, 2013). In fact, strengthening capital rituals through the development of tourism could benefit local communities (Hsieh et al., 2017). The Kakara and Limau community utilized the ritual, social, and natural capital to access financial, human, and physical capital. This showed the existence of diversification, expansion, and transformation of forms of capital as coping and survival strategies. The customary community in Limau and Kakara villages maintained their local cultural identity through rituals inherited from their ancestors amid social changes due to the development of multi-ethnic relations as a result of globalization. They were being adaptive to technological developments but kept on fighting on acculturation and assimilation by strengthening the cultural base through local customary rituals, even though they were in a multicultural space.

The context of the main livelihoods of traditional communities in Limau and Kakara villages was being farmers and substitute fishermen. Through the development of tourism in the village, the Kakara and Limau community had the opportunity to improve their economy. This showed that there was an opportunity for intensification of livelihood outcomes, diversification and transformation (Eshun et al., 2019). For fishermen, Allison and Ellis (2001) viewed that their strategies emphasized on critical factors and livelihood vulnerability. Furthermore, Platteau (1989) argued that modernization also influenced the form of adaptation of fishermen to maintain the sustainability of their livelihoods.
Whereas for farmers, $\mathrm{Xu}$ et al. (2015) argued that their strategies depended on the knowledge and skills to increase crop production. However, Jansen et al. (2006) found that sustainable development policies also had a significant influence on vulnerability context of household livelihood strategies.

Chambers and Conway (1991) perspective on sustainable livelihood approach emphasized on the availability of resources in the form of social, financial, natural, human, and physical capital. However, the livelihood assets described were still general. Meanwhile, this article shows the existence of ritual capital as a resource of customary community in Kakara and Limau village which increased the capability of access to other capital. Burger and Christen (2011) stated that the capability to access capital was one of the factors of sustainable livelihood. Thus, ritual capital had an essential role in achieving sustainable livelihood because of the existence of cultural-based collective capabilities (Jackson, 2005).

\section{Conclusion}

The results of this study are theoretical recommendations on the conceptual framework of sustainable livelihoods approach which were reconstructed by Robert John Haylock Chambers and Gordon Richard Conway in 1992. The main idea offered based on the results of this study is ritual in the traditions of rural community, as a form of capital that supports the sustainability of livelihoods. The traditional rituals of the Limau and Kakara villages in North Halmahera Regency mobilize community capabilities to access social capital, human capital, natural capital, financial capital, and physical capital. The existence of the indigenous rituals not only maintain the community livelihoods in rural or remote areas but also becomes a tourist attraction. Rituals have become a way of life for Limau and Kakara community and affect the sustainable use of natural resources without damaging the environment. Therefore, the ritual is a form of capital owned by indigenous peoples to maintain sustainable livelihoods and sustainable tourism for sustainable development.

\section{Recommendation}

The results of this study need to be considered seriously for a sustainable livelihood of the customary community in Indonesia who utilize ritual capital for their livelihood capability and security. In the context of developing rural tourism, the role of local, sub-district and rural governments is needed in formulating local-cultural-values-based tourism development policies so that they are sustainable. On the other hand, this research is limited to the cultural aspects of local communities in the perspective of sustainable livelihood approach. Therefore, future researches are suggested to study on the collaboration among stakeholders as an essential part in achieving livelihood sustainability. Thus, the new cultural paradigm in sustainable rural tourism development in Indonesia does not seem static but dynamic

\section{References}

Adzawala, W., \& Kane, A. (2018). Gender perspectives of the determinants of climate adaptation: The case of 
livelihood diversification in northern Ghana. Review of Agricultural and Applied Economics, 21(2), 113-127. https://doi.org/10.15414/raae.2018.21.02.113-127

Albore, A. (2018). Review on determinants of sustainable rural livelihood diversification of small holder farmer in Ethiopia. International Journal of Advanced Research (IJAR), 6(2), 251-259. https://doi.org/10.21474/ IJAR01/6436

Allison, E. H., \& Ellis, F. (2001). The livelihood approach and management of small-scale fisheries. Marine Policy, 25(5), 377-388. https://doi.org/10.1016/S0308597X(01)00023-9

Amal, A. M. (2010). Kepulauan rempah-rempah: Perjalanan sejarah Maluku Utara 1250-1950. Jakarta: Kepustakaan Populer Gramedia.

Ashley, C., \& Carney, D. (1999). Sustainable livelihood: Lesson from early experience. London: DFID.

Barbulescu, A. (2014). Official order and ritual disobedience in Transnistria's ghettos. Sfera Politicii, 22(6), 114-126.

Barrows, C. W. (2000). An exploratory study of food and beverage training in private clubs. International Journal of Contemporary Hospitality Management, 12(3), 190-197. https://doi.org/10.1108/09596110010320751

Baumman, P. (2000). Sustainable livelihood and political capital: Arguments and evidence from decentralization and natural resource management in India. London: ODI Working Paper.

Becker, G. (1994). Human capital: A theoretical and empirical analysis with special reference to education. Chicago: The University of Chicago Press. https://doi.org/10.7208/chicago/9780226041223.001.00 01

Belete, A. (2018). Determinants of rural household's livelihood strategies in Machakel Woreda, East Gojjam zone, Amhara Nation Regional State, Ethiopia. Developing Country Studies. 8(10),1-6.

Bollingtoft, A., Ulhoi, J. P., Madsen, A. H., Neergard, H. (2003). Effect of financial factors on the performance of new venture companies in high tech and knowledge intensive industries: An empirical study in Denmark. International Journal of Management, 20(1), 535-547.

Bourdieu, P. (1986). Le capital social: Notes provisoires. Actes de la recherché en sciences sociales, 31(1980), $2-3$.

Bourdieu, P., \& Wacquant, L. (1992). An invitation to reflexive sociology. Chicago: University of Chicago Press.

Burger, P., \& Christen, M. (2011). Towards a capability approach of sustainability. Journal of Cleaner Production, 19(8), 787-795. https://doi.org/10.1016/ j.jclepro.2010.06.019

Chambers, R., \& Conway, G. (1991). Sustainable rural livelihood: Practical concepts for $21^{\text {st }}$ century. Brighton: IDS Working Paper 296.

Coleman, J. (1998). Social capital in the creation of human capital. The American Journal of Sociology, 94(1), 97-100.

Coleman, J. S. (1994). Foundation of social theory. Cambridge MA: Belknap Press.

Costa, C. (2001). An emerging tourism planning paradigm? A comparative analysis between town and tourism planning. International Journal of Tourism Research, 3(6), 425-441. https://doi.org/10.1002/jtr.277

Cottyn, I. (2018). Livelihood trajectories in context of repeated displacement: Empirical evidence from Rwanda. Sustainability, 10(10), 1-13. https://doi.org/ 10.3390/su10103521

Cronje, C. J., \& Moolman, S. (2013). Intellectual capital: Measurement, recognition and reporting. South African Journal of Economic and Management Sciences, 16(1), 1-12. https://doi.org/10.4102/sajems.v16il.244

Dereje, T., \& Abeje, B. (2018). Rural livelihood strategies and household food security of farmers surrounding Derba Cement Factory, Oromia Region, Ethopia. Rural Sustainability Research, 40(335), 2-7. https://doi.org/ 10.2478/plua-2018-0006

Dhesi, A. S. (2000). Social capital and community development. Community Development Journal, 35(3), 199-214. https://doi.org/10.1093/cdj/35.3.199

Dwivedi, S. K., \& Hussain, M. S. (2018). Core responsibilities of government, local communities, state tourism authority for various drawbacks and lacks in facilities development, protection and conservation of sun temple at Konark. International Journal of Innovative Knowledge Concepts. 6(5), 69-77.

Ekins, P., Simon, S., Deutsch, L., Folke, C., \& De Groot, R. (2003). A framework for the practical applications of the concept of critical natural capital and strong sustainability. Ecological Economics, 44(2-3), 165-185. https://doi.org/10.1016/S09218009(02)00272-0

Eshun, I., Golo, H. K., \& Dankwa, S. (2019). Livelihood strategies and outcomes of fisher folk in selected rural coastal communities in Ghana. Journal of Culture, Society and Development, 48(2019), 35-45. https://doi.org/10.7176/JCSD/48-05

Fukuyama, F. (1995). Trust: The social virtues and the creation of prosperity. London: Hamish Hamilton.

Fukuyama, F. (2002). Social capital, civil society and development. Third World Quarterly, 22(1), 7-20. 


\section{https://doi.org/10.1080/713701144}

Galor, O., \& Moav, O. (2004). From physical to human capital accumulation: Inequality and the process of development. The Review of Economic Studies, 71(4), 1001-1026. https://doi.org/10.1111/0034-6527.00312

Gariggos, S. F. J., Bottela, C. M. D., \& Gonzales, C. T. F. (2018). Social capital, human capital, and sustainability: A bibliometric and visualization analysis. Sustainability, 10(12), 1-19. https://doi.org/10.3390/su10124751

Gebru., G. W., Ichoku, H.E., \& Phil-Eze, P. O. (2018). Determinants of livelihood diversification strategies in eastern Tigray region of Ethiopia. Agriculture \& Food Security, 7(1), 1-9. https://doi.org/10.1186/s40066-0180214-0

Gelan, D. T. (2018). Livelihood diversification determinants in the Teff growing area of east Shoa zone of Oromia region, Ethiopia. Research on Humanities and Social Science, 8(23), 9-18.

Gracial, T. P. J., \& Martinez, S. P. (2007). Effects of working capital management on SME profitability. International Journal of Managerial Finance, 3(2), 164-177. https://doi.org/10.1108/17439130710738718

Hall, P. (1999). Social capital in Britain. British Journal of Political Science, 29(3), 41-61. https://doi.org/10.1017/ S0007123499000204

Handoko, W. (2017). The expasion of islamic power of Ternate sultanate in the east coastal of North Halmahera. Kapata Arkeologi, 13(1), 95-108. https://doi.org/10. 24832/kapata.v13i1.396

Harper, R. (2001). Social capital: A review of the literature. London: Social Analysis and Reporting Division, Office of National Statistics.

Hines, T. (2000). An evaluation of two qualitative methods (focus group interviews and cognitive maps) for conducting research into entrepreneurial decision making. Qualitative Market Research: An International Journal, 3(1), 7-16. https://doi.org/10.1108/1352275 0010310406

Hsieh, C.M., Tsai, B.K., \& Chen, H. S. (2017). Residents' attitude toward aboriginal cultural tourism development: An integration of two theories. Sustainability, 9(6), 903. https://doi.org/10.3390/su9060903

Jackson, W. A. (2005). Capabilities, culture and social structure. Review of Social Economy, 63(1), 101-124. https://doi.org/10.1080/00346760500048048

James, A., \& Bansilal, S. (2010). Indigenous knowledge practitioners' sustainable livelihood practices: A case study. Indilinga: Agrican Journal of Indigenous Knowledge System, 9(1), 73-83.

Jansen, H. G. P., Pender, J. L., Damon, A., Wielemaker, W., \&
Schipper, R. A. (2006). Policies for sustainable development in the hillsides of Honduras: A quantitative livelihoods approach. Agricultural Economics, 34(2), 141-153. https://doi.org/10.1111/j.1574-0864. 2006.00114.x

Ketut, S. (2012). Cultural capital as the basis for developing tourism at Kuta traditional village. Mudra, 27(3), $315-323$.

Kippendorf, K. (1980). Content analysis: An introdution to its methodology. Beverly Hills: Sage Publications.

Kotalaha, J., Sasongko, G. (2018). Local knowledge "Makiriwo" in the sustainable livelihood perspective (case of Apulea coconut farm community in North Halmahera regency, Indonesia). Sodality, 6(3), 253-261. https://doi.org/10.22500/sodality.v6i3.25455

Kotarski, H. (2012). The role of human and social capital in the local and regional development on the example of Podkarpackie Viovodeship. Studia Humanistyczne AGH, 11(4), 183-190. https://doi.org/10.7494/human.2012. 11.4.183

Krueger, R.A. (1994). Focus groups: A practical guide for applied research. Thousand Oaks: Sage.

Kuzmin, O. Y., \& Shakhno, A. Y. (2018). The national model of state regulation of human capital development under conditions of global competition. Provlemi Ekonomiki, 2(36), 88-97.

Lapian, A. B. (2009). Orang laut-bajak laut-raja laut: sejarah kawasan laut sulawesi abad XIX. Jakarta: Komunitas Bambu.

Luchian, I. (2015). Globalization and financial crisis. Economy and Sociology, 3(3), 107-111.

Macbeth, j., Carson, D., \& Northcote, J. K. (2004). Social capital, tourism and regional development: SPCC as a basis for innovation and sustainability. Current Issues in Tourism, 7(6), 502-522. https://doi.org/10.1080/ 1368350050408668200

Mamman, A., Kamoche, K., Zakaria, H. B., \& Agbedi, M. (2018). Developing human capital in Africa: Carving a role for human resource professionals and practitioners. Human Resources Development International, 21(5), 444-462. https://doi.org/10.1080/13678868.2018. 1464290

McAreavey, R., \& McDonagh, J. (2011). Sustainable rural tourism: Lessons for rural development. Sociologia Ruralis, 51(2), 175-194. https://doi.org/10.1111/j.14679523.2010.00529.x

Meyer, E. (2013). Rituals and social capital in the book of Levicticus? an attempt at an interdisciplinary discussion. Dutch Reformed Theological Journal, 54(3), 263-275. https://doi.org/10.5952/54-3-4-381 
Moe, T., Alfsen, K. H., \& Greaker, M. (2015). Sustaining welfare for future generations: A review note on the capital approach to the measurement of sustainable development. Challenges in Sustainability, 1(2013), 16-26. https://doi.org/10.12924/cis2013.01010016

Moser, C., North A., Conway T., Ferguson, C., \& Vizard, P. (2001). To claim our right: Livelihood security, human rights and sustainable development. London: ODI.

Naping, H., Asba, R., Arsyad, A., Hamdat, S., Kahar., Sumantri, I., ... \& Irwan, L. (2013). Halmahera Utara: Sejarah perkembangan peradaban di bumi Hibualamo. Makassar: Yayasan Bina Generasi.

Natallia, K. (2014). Human capital as the major financing in the welfare state. Megatrend Revija, 11(1), 73-88. https://doi.org/10.5937/MegRev1401073K

Nawrotzki, R., Hunter, L. M., \& Dickison, T. W. (2012). Natural resources and rural livelihoods: Differences between migrants and non-migrants in Madagascar. Demographic Research, 26(24), 661-700. https://doi.org/10.4054/DemRes.2012.26.24

Neilson, J, \& Shonk, F. (2014). Chained to development? livelihoods and global value chains in the coffeeproducing Toraja region of Indonesia. Australian Geographer, 45(3), 269-288. https://doi.org/10.1080/ 00049182.2014 .929998

Njatrijani, R. (2018). Local knowledge in Semarang culture perspectives. Gema Keadilan, 5(1), 16-31. https://doi.org/10.14710/gk.5.1.16-31

Norton, A., \& Foster, M. (2001). The potential of using sustainable livelihoods approaches in poverty reduction strategy papers. Working Paper 148. London: ODI.

Picard, M. (2008). Balinese identity as tourist attraction : From cultural tourism to Bali erect. Tourist Studies, 8(2), 155-173. https://doi.org/10.1177/1468797608099246

Platteau, J. (1989). The dynamics of fisheries development in developing countries: A general overview. Development and Change, 20(4), 565-597. https://doi.org/10. 1111/j.1467-7660.1989.tb00358.x

Pranoto, H., \& Wibowo, A. (2018). The role of local wisdom "Piil Pesenggiri" in multi-ethnic counseling services. Jurnal Bimbingan Konseling Indonesia, 3(2), 36-42. https://doi.org/10.26737/jbki.v3i2.714

Putnam, R. (2000). Bowling alone: America's declining social capital. Journal of Democracy, 6(1), 65-78. https://doi.org/10.1353/jod.1995.0002

Putnam, R. D. (1993). Making democracy work: Civic traditions in modern Italy. Princeton: Princeton University Press. https://doi.org/10.2307/j.ctt7s8r7

Rakodi, C. (2002). A capital assets framework for analyzing household livelihood strategies: Implications for policy. Development Policy Review, 14(3), 315-342. https://doi.org/10.1111/1467-7679.00090

Rankin, K. N. (2002). Social capital, microfinance, and the politics of development. Feminist Economics, 8(1), 1-24. https://doi.org/10.1080/13545700210125167

Richard, G., \& Rotariu, I. (2013). The impact of cultural events on tourism development: Sibiu- the European cultural capital. Seria Economie, 1(1), 6-12.

Robaa, B., \& Tolossa, D. (2016). Rural livelihood diversification and its effects on household food security: A case study at Damota gale Woreda, Wolayta, Southern Ethiopia. Eastern Africa Social Science Research Review, 32(1), 93-118. https://doi.org/10.1353/eas. 2016.0001

Robbins, D. (2000). Bourdieu and culture. London: Sage. https://doi.org/10.4135/9781446218549

Robison, L., J., Schmid, A. A., \& Sile, M. E. (2000). Is social capital really capital? Review of Social Economy, 60(1), 1-21.https://doi.org/10.1080/00346760110127074

Romanos, M., \& Jenkins, L. D. (2013). Changing cultural developments along a tourist route in Bali. AlmatoruismJournal of Tourism, Culture and Territorial Development, 4(8): 19-31. https://doi.org/10.6092/issn. 2036-5195/4081

Rothstein, B. (2001). Social capital in the social democratic welfare sociability. Politics and Society, 29(2), 27-41. https://doi.org/10.1177/0032329201029002003

Schultz, T. W. (1961). Investment in human capital. The American Economic Review, 1(2), 1-17.

Scoones, I. (1998). Sustainable rural livelihood: A framework for analysis. Brighton: IDS Working Paper 71.

Sedana, G., Ambarawati, I. G. A. A., \& Windia, W. (2014). Strengthening social capital for agricultural development: Lessons from Guama, Bali, Indonesia. Asian Journal of Agriculture and Development, 11(2), 39-49.

Sergej, F. (2012). Religious capital and religious rewards: A study in the economics of religious life. Panoeconomicus, 59(1), 117-127. https://doi.org/ 10.2298/PAN1201117F

Shilling, C. (2004). Physical capital and situated action: A new direction for corporeal sociology. British Journal of Sociology of Education, 25(4), 473-487. https://doi.org/ $10.1080 / 0142569042000236961$

Sullivan, A., \& Sheffrin, D. M. (2003). Economic principles in action. New Jersey: Pearson Prentice Hall.

Sumadi, K. (2012). Tourism development basis in traditional 
village of Kuta. International Journal of linguistics, Literature and Culture, 2(3), 124-132.

Swart, I., Haar, G.T., Wepener, C., \& Barndard, M. (2010). The role of religious in social capital formation for poverty alleviation and social development: Theoretical and methodological points of departure of a South African exploration. Religion \& Theology, 17(1), 61-82. https://doi.org/10.1163/157430110X517924

Tanjung, F. (2019). The influence of social capital in economic development in Indonesia: Macro Data Analysis of 2012 and 2014. International Journal of Advances in Scientific Research and Engineering, 5(3), 116-123. https://doi.org/10.31695/IJASRE.2019.33117

Taylor, S. (2017). Issues in measuring success in communitybased indigenous tourism: Elites, kin groups, social capital, gender dynamics and income flows. Journal of Sustainable Tourism, 25(3), 433-449. https://doi.org/ $10.1080 / 09669582.2016 .1217871$

Turner, S. (2007). Small-scale enterprise livelihoods and social capital in eastern Indonesia: Ethnic embeddedness and exclusion. The Professional Geographer, 5(4), 407-420. https://doi.org/10.1111/j.1467-9272.2007. 00631.x

van Praag, C. (2003). Business survival and success of young business owners. Journal of Small Business Economics, 21(1), 1-17. https://doi.org/10.1023/A:1024453200297
Wang, C.M., \& Woods, M. (2013). The role of Guangxi in rural social movements: Two case studies from Taiwan. Journal of Agrarian Change, 13(2), 197-212. https://doi.org/10.1111/j.1471-0366.2012.00359.x

Wepener, C. (2010). Snert: Ritual-liturgical measurements and recipes for social capital. Verbum et Ecclesia, 31(1), 1-7.https://doi.org/10.4102/ve.v31i1.407

Whiteley, P. F. (2000). Economic growth and social capital. Political Studies, 48(3), 43-66. https://doi.org/10.1111/ 1467-9248.00269

Wiklund, J., \& Sepherd, D. (2005). Entrepreneurial orientation and small business performance: A configurational approach. Journal of Business Venturing, 20(1), 71-91. https://doi.org/10.1016/j.jbusvent.2004. 01.001

Woolcock, M. (1998). Social capital and economic development toward a theoretical synthesis and policy framework. Theory and Society, 2(1), 1-7. https://doi.org/10.1023/A:1006884930135

Xu, D., Zhang, J., Rasul, G., Liu, S., Xie, F., Cao, M., \& Liu, E. (2015). Household livelihood strategies and dependence on agriculture in the mountainous settlements in the Tree Georges Reservoir Area, China. Sustainability, 7(5): 1342-1355. https://doi.org/ $10.3390 / \mathrm{su} 7054850$ 